\title{
Effect of antisera against eggs and zonae pellucidae on fertilization and development of mouse eggs in vivo and in culture
}

\author{
Y. Tsunoda* and M. C. Chang \\ Worcester Foundation for Experimental Biology, \\ Shrewsbury, Massachusetts 01545, U.S.A.
}

\begin{abstract}
Summary. A single intraperitoneal injection of female mice with rabbit antisera against denuded mouse eggs and isolated zonae pellucidae inhibited fertilization for at least 25-30 days. Intraperitoneal injection appeared to be more effective and lasted longer than subcutaneous or intramuscular injection but oral administration had no effect. Such a passive immunization of females given after fertilization had no effect on embryonic development or the sex ratio of fetuses. The fertilizing capacity of mouse spermatozoa was suppressed by treatment of the sperm suspension with anti-egg but not with anti-zona serum. Treatment of mouse eggs with these antisera did not affect their development to blastocysts in culture but did inhibit the shedding of the zona pellucida and attachment to the dish.
\end{abstract}

\section{Introduction}

It has been reported that early mouse embryos cannot survive in the presence of an antiserum raised in rabbits against mouse cumulus-oocytes or eggs at various stages of development and that the zona pellucida of eggs is highly antigenic (Glass \& Hanson, 1974). Mouse fertilization in vitro and in vivo (passive immunization of females) can also be inhibited by antiserum against denuded mouse eggs (Tsunoda, 1977) or isolated zonae pellucidae (Tsunoda \& Sugie, 1977). The present study was undertaken to determine (1) the duration of effect and the most effective route of administration of the antiserum for passive immunization of female mice to inhibit fertilization, (2) the effect of passive immunization after fertilization on embryonic development and implantation, and (3) the effect of antisera on the fertilizing capacity of spermatozoa and on the development of mouse eggs in culture.

\section{Materials and Methods}

The procedures for obtaining rabbit antiserum against denuded mouse eggs (a total of 3600 denuded eggs for 6 injections) or isolated zonae pellucidae (a total of 7200-9900 zonae for 8-11 injections) of ddY mice (a closed colony; Matsumoto Co., Japan) have been described elsewhere (Tsunoda, 1977; Tsunoda \& Sugie, 1977). Unabsorbed antisera were used in this study.

Experiment 1. To determine the duration of the effect of passive immunization, mature CD-1 mice were injected intraperitoneally with $0.3 \mathrm{ml}$ antiserum (anti-egg or anti-zona) 5-40 days before the induction of superovulation by injection of PMSG and hCG (Tsunoda \& Chang, 1975). The same volume of normal serum from non-immunized rabbits was used for control injections. The females were allowed to mate with fertile males and killed 1 day after mating (spermatozoa in vaginal smear) to count the numbers of fertilized eggs (Tsunoda \& Chang, 1975).

Experiment 2. To examine the effective routes of administration, mice were induced to superovulate by injections of 5 i.u. PMSG and 5 i.u. hCG $40-48 \mathrm{~h}$ later. The anti-egg serum $(0.05-1.0 \mathrm{ml})$ was injected intraperitoneally, subcutaneously, intramuscularly or by gavage $7-10 \mathrm{~h}$ after the injection of PMSG. Soon after injection of hCG the females were caged with fertile males and killed 1 day after mating (spermatozoa in vaginal smear) to determine the numbers of eggs fertilized.

\section{* Present address: National Institute of Animal Industry, Chiba 280, Japan.}


Experiment 3. The effects of the anti-egg serum on embryonic development were studied by treating mice with a single intraperitoneal injection of $0.3 \mathrm{ml}$ saline $(0.154 \mathrm{M}-\mathrm{NaCl}), 0.3 \mathrm{ml}$ normal rabbit serum or $0.3 \mathrm{ml}$ anti-egg serum 1 day or 4 days after mating (spermatozoa in vaginal smear). The mice were killed on the 18th day after mating and the numbers of resorbing and live fetuses and the fetal sex ratio were recorded.

Experiment 4. For the study of the effect of the antisera on the fertilizing capacity of spermatozoa, epididymal spermatozoa from mature CD-1 mice were suspended in the mouse fertilization medium (Toyoda, Yokoyama \& Hosi, 1971) supplemented with $20 \%$ normal rabbit serum or $20 \%$ anti-egg or anti-zona serum. A volume $(0.05 \mathrm{ml})$ of the sperm suspension $\left(20-40 \times 10^{6}\right.$ cells $\left./ \mathrm{ml}\right)$ was instilled, $30-60 \mathrm{~min}$ after preparation at $37^{\circ} \mathrm{C}$, at laparotomy under sodium pentobarbitone anaesthesia, into the lumen of each uterine horn, via the cervix, of mice induced to superovulate. Uterine insemination was performed about $10 \mathrm{~h}$ after injection of $\mathrm{hCG}$ and the eggs were examined 1 day after insemination.

Experiment 5. To study the effect of the antisera on the development of eggs in culture, 8-celled eggs were recovered from the oviducts of untreated mice and divided into three groups. The flushing medium was a medium based on Tyrode's solution (Whittingham, 1971) and the eggs were treated with the medium supplemented with $20 \%$ (a) normal rabbit serum, (b) anti-egg serum or (c) antizona serum for $30 \mathrm{~min}$ at $37^{\circ} \mathrm{C}$. The treated eggs were then washed three times with the same medium and cultured under oil at $37^{\circ} \mathrm{C}$ in $5 \% \mathrm{CO}_{2}$ in air. After culture for 2 days the number of eggs which had developed into blastocysts was recorded and $20 \%$ fetal calf serum (Difco Laboratories) was added to the culture medium. After culture for another 2 days the numbers of blastocysts that had shed their zona pellucida and attached to the dish (Tsunoda, Makino, Iritani \& Nishikawa, 1977) were recorded.

The statistical significance of the results was determined by $\chi^{2}$ tests.

\section{Experiment 1}

\section{Results}

As shown in Table 1 the effect of anti-egg or anti-zona serum on the inhibition of fertilization lasted for 25-30 days. A precipitate of varied intensity was observed under dark-field illumination on the zona pellucida of all the eggs recovered 5-30 days after a passive immunization of females with either antiserum. Ovulation was not affected by the treatment with antisera because there was no failure of ovulation or decreased numbers of eggs. However, antiserum treatment did not cause permanent sterility because 4 mice which were passively immunized with anti-egg serum 60-74 days before mating produced normal litters of $11 \cdot 8 \pm 2 \cdot 5$ (s.d.) young/mouse.

Table 1. Duration of effect on fertilization of passive immunization of female mice with anti-egg or anti-zona serum

\begin{tabular}{|c|c|c|c|c|c|}
\hline \multirow[b]{2}{*}{ Serum } & \multirow[b]{2}{*}{$\begin{array}{c}\text { Time of injection } \\
\text { (days before mating) }\end{array}$} & \multirow{2}{*}{$\begin{array}{l}\text { No. of females with } \\
\text { fertilized eggs/no. } \\
\text { of females mated }\end{array}$} & \multicolumn{2}{|c|}{ No. of eggs } & \multirow[b]{2}{*}{$\begin{array}{c}\text { Zona } \\
\text { precipitate* }\end{array}$} \\
\hline & & & Examined & $\begin{array}{c}\text { Fertilized } \\
(\%)\end{array}$ & \\
\hline \multirow[t]{3}{*}{ Normal } & 10 & $4 / 4$ & 88 & $87(98.9)$ & - \\
\hline & 20 & $4 / 4$ & 117 & $110(94)$ & - \\
\hline & 30 & $3 / 3$ & 87 & $87(100)$ & - \\
\hline \multirow[t]{7}{*}{ Anti-egg } & 5 & $0 / 2$ & 49 & 0 & ++ \\
\hline & 10 & $0 / 4$ & 113 & 0 & $++t$ \\
\hline & 15 & $0 / 4$ & 87 & 0 & $++t$ \\
\hline & 20 & $0 / 4$ & 80 & 0 & $+t$ \\
\hline & 25 & $1 / 4$ & 135 & $1(0.7)$ & +++ \\
\hline & 30 & $3 / 4$ & 115 & $42(36 \cdot 5)$ & $+\sim+++$ \\
\hline & 40 & $4 / 4$ & 129 & $118(91 \cdot 5)$ & - \\
\hline \multirow[t]{3}{*}{ Anti-zona } & 20 & $0 / 2$ & 36 & 0 & $++t$ \\
\hline & 25 & $0 / 2$ & 28 & 0 & +++ \\
\hline & 30 & $2 / 2$ & 66 & $3(4 \cdot 5)$ & +++ \\
\hline
\end{tabular}




\section{Experiment 2}

Table 2 shows that oral administration of 0.3 or $1 \mathrm{ml}$ anti-egg serum did not inhibit fertilization, but intraperitoneal, subcutaneous and intramuscular injections of $0.3 \mathrm{ml}$ antiserum completely inhibited fertilization. These 3 routes were partly effective at lower doses, but intraperitoneal injection was the most effective at the lowest dose (Table 2). The intensity of the precipitate on the zona pellucida was consistent with these results.

Table 2. Effect of different routes of administration and doses of anti-egg serum for the inhibition of fertilization in mice

\begin{tabular}{|c|c|c|c|c|c|}
\hline \multirow[b]{2}{*}{ Route } & \multirow[b]{2}{*}{$\begin{array}{c}\text { Dose } \\
(\mathrm{ml})\end{array}$} & \multirow{2}{*}{$\begin{array}{l}\text { No. of females with } \\
\text { fertilized eggs/no. } \\
\text { of females mated }\end{array}$} & \multicolumn{2}{|c|}{ No. of eggs } & \multirow[b]{2}{*}{$\begin{array}{c}\text { Zona } \\
\text { precipitate }\end{array}$} \\
\hline & & & Recovered & $\begin{array}{c}\text { Fertilized } \\
(\%)\end{array}$ & \\
\hline Oral gavage & $\begin{array}{l}1 \\
0.3\end{array}$ & $\begin{array}{l}2 / 2 \\
2 / 2\end{array}$ & $\begin{array}{l}23 \\
57\end{array}$ & $\begin{array}{l}23(100) \\
57(100)\end{array}$ & - \\
\hline Intraperitoneal injection & $\begin{array}{l}0.3 \\
0.1 \\
0.05\end{array}$ & $\begin{array}{l}0 / 2 \\
4 / 4 \\
4 / 4\end{array}$ & $\begin{array}{l}30 \\
85 \\
80\end{array}$ & $\begin{array}{l}0 \dagger \\
21(24 \cdot 7) \dagger \\
32(40 \cdot 0) \dagger \ddagger\end{array}$ & $\begin{array}{c}+++ \\
+ \\
\pm\end{array}$ \\
\hline Subcutaneous injection & $\begin{array}{l}0.3 \\
0.1 \\
0.05\end{array}$ & $\begin{array}{l}0 / 2 \\
3 / 4 \\
4 / 4\end{array}$ & $\begin{array}{l}25 \\
37 \\
46\end{array}$ & $\begin{array}{l}0 \dagger \\
4(10.8) \dagger \\
40(87.0)\end{array}$ & $\begin{array}{c}+1 \\
+ \\
\pm\end{array}$ \\
\hline Intramuscular injection & $\begin{array}{l}0.3 \\
0.1 \\
0.05\end{array}$ & $\begin{array}{l}0 / 2 \\
2 / 4 \\
4 / 4\end{array}$ & $\begin{array}{r}39 \\
103 \\
56\end{array}$ & $\begin{array}{l}0 \dagger \\
36(35.0) \dagger \\
42(75 \cdot 0)\end{array}$ & $\begin{array}{c}++ \\
+ \\
\pm\end{array}$ \\
\hline
\end{tabular}

* -, no precipitate; +++ , most intense precipitate.

$\dagger$ Significantly different from results with oral dosing, $P<0.001$.

‡ Significantly different from values for $0.05 \mathrm{ml}$ dose given s.c. or i.m., $P<0.001$.

\section{Experiment 3}

There were no significant differences in the numbers of live fetuses and the fetal sex ratios of the female mice injected with saline, normal rabbit serum or anti-egg serum (Table 3 ).

Table 3. Effect of anti-egg serum injected after mating on the embryonic development and sex ratio of fetuses

\begin{tabular}{|c|c|c|c|c|c|c|c|}
\hline \multirow{2}{*}{$\begin{array}{c}\text { Day of } \\
\text { injection }\end{array}$} & \multirow[b]{2}{*}{ Serum } & \multirow{2}{*}{$\begin{array}{c}\text { No. of } \\
\text { pregnant } \\
\text { females }\end{array}$} & \multicolumn{2}{|c|}{ No. of fetuses } & \multirow{2}{*}{$\begin{array}{l}\text { No./female } \\
\text { (mean } \pm \text { s.d.) }\end{array}$} & \multicolumn{2}{|c|}{ Sex of fetuses } \\
\hline & & & Resorbing & Live & & Male $(\%)$ & Female $(\%)$ \\
\hline Day 1 & $\begin{array}{l}\text { None (saline) } \\
\text { Normal } \\
\text { Anti-egg }\end{array}$ & $\begin{array}{l}4 \\
4 \\
4\end{array}$ & $\begin{array}{l}0 \\
1 \\
2\end{array}$ & $\begin{array}{l}37 \\
40 \\
40\end{array}$ & $\begin{array}{r}9.3 \pm 2.9 \\
10.0 \pm 2.3 \\
10.0 \pm 2.6\end{array}$ & $\begin{array}{l}21(56 \cdot 8) \\
20(50 \cdot 0) \\
21(52 \cdot 5)\end{array}$ & $\begin{array}{l}16(43 \cdot 2) \\
20(50 \cdot 0) \\
19(47 \cdot 5)\end{array}$ \\
\hline Day 4 & $\begin{array}{l}\text { None (saline) } \\
\text { Normal } \\
\text { Anti-egg }\end{array}$ & $\begin{array}{l}4 \\
4 \\
4\end{array}$ & $\begin{array}{l}0 \\
1 \\
1\end{array}$ & $\begin{array}{l}44 \\
41 \\
41\end{array}$ & $\begin{array}{l}11.0 \pm 1.4 \\
10.3 \pm 1.0 \\
10.3 \pm 1.3\end{array}$ & $\begin{array}{l}21(47 \cdot 7) \\
24(58 \cdot 5) \\
26(63 \cdot 4)\end{array}$ & $\begin{array}{l}23(52 \cdot 3) \\
17(41 \cdot 5) \\
15(36 \cdot 6)\end{array}$ \\
\hline
\end{tabular}

\section{Experiment 4}

As shown in Table 4, only the exposure to the anti-egg serum resulted in a significant reduction of fertilization. 
Table 4. Fertilizing capacity of mouse spermatozoa exposed to antisera before intrauterine insemination of mice

\begin{tabular}{lcrr}
\hline & \multirow{2}{*}{$\begin{array}{c}\text { No. of females with } \\
\text { fertilized eggs/no. } \\
\text { of females inseminated }\end{array}$} & Examined & Fertilized (\%) \\
\cline { 3 - 4 } & $6 / 6$ & 114 & $108(94 \cdot 7)$ \\
Normal serum & $4 / 7$ & 155 & $11(7 \cdot 1)^{*}$ \\
Anti-egg serum & $5 / 5$ & 113 & $111(98 \cdot 2)$ \\
Anti-zona serum & & & \\
\hline
\end{tabular}

$* P<0.001$ compared with the other two values.

\section{Experiment 5}

Treatment of 8-celled eggs with anti-egg or anti-zona serum had no adverse effect on the development of eggs into blastocysts in culture, although there was a slight but significant inhibition of the shedding of the zona pellucida and the attachment of the blastocysts to the dish (Table 5).

Table 5. Effect of treatment of 8-cell mouse eggs with anti-egg and anti-zona sera for 30 min on the development in culture ( $5-7$ tests/treatment)

\begin{tabular}{lccc}
\hline Treatment & $\begin{array}{c}\text { No. of eggs } \\
\text { cultured }\end{array}$ & $\begin{array}{c}\text { No. of eggs developed } \\
\text { into blastocysts }(\%)\end{array}$ & $\begin{array}{c}\text { No. of blastocysts without } \\
\text { zona pellucida and attached } \\
\text { to the dish }(\%)\end{array}$ \\
\hline $\begin{array}{l}\text { Normal serum } \\
\text { Anti-egg serum }\end{array}$ & 57 & $50(87 \cdot 7)$ & $45(90 \cdot 0)$ \\
Anti-zona serum & 70 & $64(91 \cdot 4)$ & $45(70 \cdot 0)^{*}$ \\
\hline
\end{tabular}

* $P<0.05$ compared with value for normal serum.

\section{Discussion}

It has been considered that inhibition of fertilization by anti-ovary serum is caused by a zona pellucida-specific antigen(s) (Shivers, 1975). The inhibitory effect on fertilization by anti-ovary serum lasts for 10-30 days in the mouse (Tsunoda \& Chang, 1976b). The present study did not investigate the shortest effective time after injection, which 1-5 $\mathrm{h}$ before ovulation as previously reported (Tsunoda \& Chang, 1976b), but did show that the effect of anti-egg and anti-zona sera lasted for at least 25-30 days, and that anti-zona serum was more effective than anti-egg serum in inhibiting fertilization. It therefore appears that anti-zona serum, anti-egg serum and anti-ovary serum are progressively less potent for inhibition of fertilization in mice. The normal litters produced 60-74 days after treatment with anti-egg serum show that the inhibitory effect is not permanent but persists for longer than the duration of 4 oestrous cycles reported for treatment with anti-hamster ovary serum (Oikawa \& Yanagimachi, 1975). The lack of effect of oral administration of anti-egg serum indicates that the antibody is digested in the alimentary tract; the other 3 routes of administration were generally equally effective although intraperitoneal injection was the best for the lowest dose.

Our observations that injection of anti-egg serum (unabsorbed) after mating had no effect on fetal development, implantation or sex ratio do not agree with the observation that administration of anti-egg (with cumulus) serum (absorbed with serum) to female mice decreased the number of implantations (Glass \& Hanson, 1974), but we have no explanation for this difference.

In previous studies, the number of eggs fertilized was significantly depressed after uterine insemination of rats (Tsunoda \& Chang, 1976a), hamsters (Tsunoda \& Chang, 1976c) and mice (Tsunoda \& Chang, 1977) with spermatozoa exposed to the respective anti-ovary serum. However, 
treatment of spermatozoa with homologous antisera to spermatozoa or testis before intrauterine insemination completely inhibited the fertilizing capacity of spermatozoa (Tsunoda \& Chang, 1977). The present study shows that antiserum to mouse eggs but not that to zonae pellucidae inhibited the fertilizing ability of mouse spermatozoa.

The results of Exp. 5 do not confirm the report that culture of mouse eggs in the presence of antiegg (with cumulus cells) serum results in rapid death of the embryos (Glass \& Hanson, 1974) or the observation that the anti-ovary serum almost completely prevented shedding of the zona pellucida in culture (Shivers, 1974). In our experiments, a precipitate on the zona pellucida was observed soon after treatment with both antisera tested but the shedding of the zona and attachment of the embryos to the dish were observed in culture, indicating their potential to implant. Whether the eggs treated with antisera could develop into fetuses after transfer is still to be determined and further study is required to determine the specific antigenicity of reproductive tissues, especially of the egg components since the antiserum to eggs seems to contain an antibody(ies) other than that against the zona pellucida.

This work was supported by a grant (HD 03472) from NICHD and a grant from the Ford Foundation; M.C.C. has a Research Career Award (HD 18,334) from the National Institute of Child Health and Human Development. The antisera were prepared at the National Institute of Animal Industry, Chiba, Japan. We thank Dr T. Sugie for advice and Mrs R. Bartke for assistance.

\section{References}

Glass, L.E. \& Hanson, J.E. (1974) An immunologic approach to contraception: localization of antiembryo and antizona pellucida serum during mouse preimplantation development. Fert. Steril. 25, 484 493.

Olkawa, T. \& Yanagimachi, R. (1975) Block of hamster fertilization by anti-ovary antibody. $J$. Reprod. Fert. 45, 487-494.

SHIVERS, C.A. (1974) Immunological interference with fertilization. In Immunological Approach to Fertility Control, pp. 223-244. Ed. E. Diczfalusy. Karolinska Institute, Stockholm.

Shivers, C.A. (1975) Antigens of the ovum as a potential basis for the development of a contraceptive vaccine. In Development of Vaccines for Fertility Regulation, pp. 81-91. Scriptor, Copenhagen.

Toyoda, Y., Yokoyama, M. \& Hosi, T. (1971) Studies on the fertilization of mouse eggs in vitro. I. In vitro fertilization of eggs by fresh epididymal sperm. Jap. J. Anim. Reprod. 16, 147-151.

TSUNODA, Y. (1977) Inhibitory effect of anti-mouse egg serum on fertilization in vitro and in vivo in the mouse. J. Reprod. Fert. 50, 353-355.

TsúnOda, Y. \& Chang, M.C. (1975) In vitro fertilization of rat and mouse eggs by ejaculated sperm and the effect of energy sources on in vitro fertilization of rat eggs. J. exp. Zool. 193, 79-86.

Tsunoda, Y. \& Chang, M.C. (1976a) Effect of antirat ovary antiserum on the fertilization of rat, mouse and hamster eggs in vivo and in vitro. Biol. Reprod. 14, 354-361.

Tsunoda, Y. \& Chang, M.C. (1976b) The effect of passive immunization with hetero and isoimmune anti-ovary antiserum on the fertilization of mouse, rat and hamster eggs. Biol. Reprod. 15, 361-365.

Tsunoda, Y. \& ChanG, M.C. (1976c) In vivo and in vitro fertilization of hamster, rat and mouse eggs after treatment with anti-hamster ovary antiserum. J. exp. Zool. 195, 409-416.

Tsunoda, Y. \& Chang, M.C. (1977) Further study of antisera on fertilization of mouse, rat and hamster eggs in vitro and in vivo. Int. J. Fert. 22, 129-139.

TsuNODA, Y. \& SUGIE, T. (1977) Inhibition of fertilization in mice by antizona pellucida antiserum. Jap. J. Zootech. Sci. 48, 784-786.

Tsunoda, Y., Makino, Y., IRItani, A. \& Nishikawa, Y. (1977) Hatching and attachment of rat blastocysts in vitro. Jap. J. Zootech. Sci. 48, 94-99.

Whittingham, D.G. (1971) Culture of mouse ova. $J$. Reprod. Fert., Suppl. 14, 7-21.

Received 20 December 1977 